\title{
藤野陽三会員が服部報公賞を受賞 Member, Dr. Yozo Fujino Received Hattori Hoko Award
}

横浜国立大学先端科学高等研究院の上席特別教授であ られる藤野陽三会員（元会長）におかれては，このたび (公財) 服部報公会から 2015 年度の報公賞を受賞されま した。

財団によると，この報公賞は，服部財団が工学に関す る研究を奨励援助し，もって学術及び科学技術の振興と 進歩発展に寄与することを目的として行っている事業の 1 つであり, 工学の進歩に著しく貢献した顕著な研究業 績に対し贈られるものです。服部報公会は, 昭和 5 年に (株) 服部時計店 (現在, セイコーホールディングス(株)) の創業者であり初代社長の服部金太郎氏が，70 歳の誕生 日を向かえたのを機に, 国家, 社会の恩に報ずるために, 私財を投じて設立された公益事業団体です (http://www.hattori-hokokai.or.jp/)。

藤野陽三先生のこれまでの長年にわたる風工学をはじ めとする構造物の振動予測や制御，モニタリングに関す る研究が高く評価されたもので, 土木工学分野では初め ての受賞とのことです。また，過去にはノーベル賞を受 賞された湯川秀樹博士も 1938 年にこの賞を受賞されて おり，非常に名誉ある賞でもあります。去る 10 月 9 日に 日本工業俱楽部にて贈呈式があり, 賞状と賞金 1000 万円 そして副賞としてお揃いのセイコークレドール腕時計が 授与されました（写真-1）。

藤野陽三先生は, 現在, 横浜国立大学の先端科学高等 研究院の「社会インフラストラクチャの安全研究ユニッ 卜」の主任研究員として, 我が国の膨大なインフラスト
ラクチャが高齢化する時代において，安全で事故や災害 に対して強勒なインフラ構築に向けて，センシング，ロ ボット技術などの先端技術の活用により効率的なインフ ラマネジメント技術の構築, 海外一の展開に尽力されて います。さらに, 内閣府が主導する「戦略的イノベーシ ヨン創造プログラム (SIP)」においては,「インフラ維持 管理・更新・マネジメント技術」のプログラムディレク ターとしてもご活躍で, 非常に多忙な日々を送られてい ます。

藤野陽三先生のこの度の受賞を契機に，今後のますま すのご活躍と後輩への指導をお願い寸るものであります。

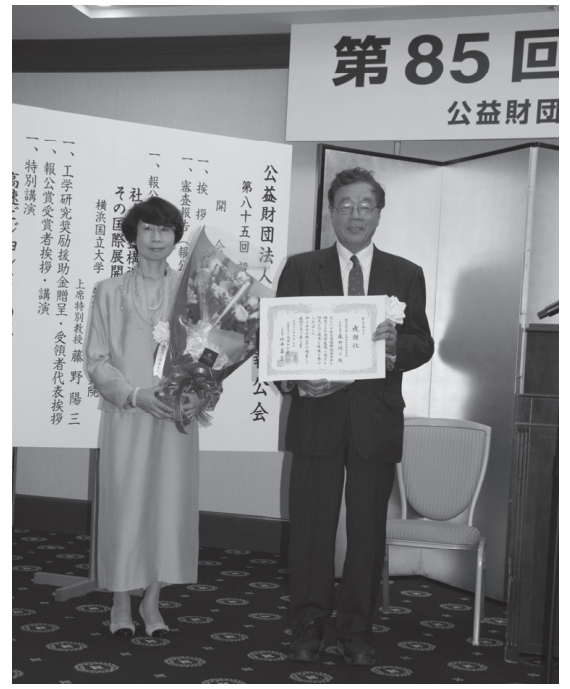

写真-1 贈呈式にて令夫人とともに

* 横浜国立大学大学院都市イノベーション研究院 教授

Professor, Faculty of Urban Innovation, Yokohama National University 